\title{
Self-help groups challenge health care systems in the US and UK
}

\section{Thomasina Borkman and Carol Munn-Giddings}

\section{Abstract}

\section{Purpose}

This research considers how self-help groups (SHGs) and self- help organizations (SHOs) contribute to consumerist trends in two different societies: United States and United Kingdom. How do the health care systems and the voluntary sectors affect the kinds of social changes that SHGs/SHOs make?

\section{Methodology/approach}

A review of research on the role of SHGs/SHOs in contributing to national health social movements in the UK and US was made. Case studies of the UK and the US compare the characteristics of their health care systems and their voluntary sector. Research reviews of two community level self-help groups in each country describe the kinds of social changes they made.

\section{Findings}

The research review verified that SHGs/SHOs contribute to national level health social movements for patient consumerism. The case studies showed that community level SHGs/SHOs successfully made the same social changes but on a smaller scale as the national movements, and the health care system affects the kinds of community changes made.

\section{Research limitations}

A limited number of $\mathrm{SHG} / \mathrm{SHO}$ within only two societies were studied. Additional SHGs/SHOs within a variety of societies need to be studied.

\section{Originality/value of chapter}

Community $\mathrm{SHGs} / \mathrm{SHO}$ are often trivialized by social scientists as just inward-oriented support groups, but this chapter shows that local groups contribute to patient consumerism and social changes but in ways that depend on the kind of health care system and societal context.

\section{Introduction}

Health consumerism as an explanatory framework in relation to the development of various health related organizations in an international context is the focus of this volume. Within this general approach, our chapter considers more narrowly how self-help groups (SHGs) and self-help organizations (SHOs) contribute to some consumerist trends in two very different health care systems: US and UK.

First, we consider the relevant consumer theory to set the stage conceptually. Second, the health care systems and the voluntary sectors including self-help/mutual aid of UK and US are described and compared to set the context. Important policy differences that shape patient and consumer opportunities in the two health care systems are highlighted. Third, a two-part thesis is advanced. The first part which has been described in the literature and is fairly well known is that SHGs/SHOs have contributed to successful national social movements in health in the US and UK including the women's health, AIDS, disability, and mental illness movements. The second but untold story is that on a community level hundreds and thousands of SHGs/SHOs have successfully changed patients into selfdetermining consumers, have challenged medical diagnoses and claims of effective treatment, and have created de-medicalized and non-stigmatized identities; the research 
evidence documenting these changes is limited. Due to space limitations, we can only present four brief case studies of SHGs, two from each country. They were selected to represent a range of social changes from the modest to the dramatic. Dramatic changes such as patient/consumers challenging a psychiatric diagnosis (UK) or mental patients creating a non-stigmatized alternative identity for themselves (US); moderate changes learned by people who stutter to challenge professional claims of treatment and cure and use their experiential knowledge to fashion workable solutions (US); modest changes of carers' groups whose sharing of experiences leads them to reject popular notions of caretaking and to become empowered to advocate for changes with their local health authorities (UK). The chapter concludes by examining what our two-part thesis contributes to theory on consumerism in health care and what can be learned from the cases that shows the different characteristics of the two health care systems.

\section{Conceptualizations of Consumerism in Health}

The Consumer Society, an iconic label to characterize modern industrialized Western societies and the title of Baudrillard's (1998) book, argues that: consumption has become institutionalized not only as a right but as the duty of citizens; we consume not just goods but also services, and human relationships become commodified. While the consumerist approach has generated extensive interest and research in many are as of sociological and cultural analysis, medical sociology has lagged behind in its attention and application of theories of consumerism to health, illness, the body, and health care (Henderson \& Petersen,2002).

One reason for the lag in the application of consumerist theory to health and illness is the nature of the economic relationship between the provider and recipient of services. Unlike the general economy, in health care there is a third party or parties who sets policies and pays the bills of the provider-either government (UK) or government and free market economy (US). Given the inevitability of third party involvement contextualizing consumerism in health care, comparative sociology studying how consumerism behaviour is expressed is invaluable. In researching mental health SHOs in England, USA, and Sweden (Borkman, Karlsson, Munn-Giddings, \& Smith, 2005) we became aware that the very different health care systems provide a context that shapes and responds to the contours of self-help/mutual aid; but, exactly how to decipher the interrelationships is not clear. In this chapter we characterize the health care systems and the voluntary sector of USA and UK viewing them as possibilities and potentialities within which self-help/mutual aid groups and organizations innovate and respond.

The 1960s and 1970s were the decades of social movements in the US. They began with the civil rights movement for blacks and other minority groups: the activism then spreading to anti-Vietnam War, women's (Morgen, 2002), gay and lesbian rights (Minton,2002), and disabilities including mental illness (Barnartt \& Scotch, 2001). The Vietnam War, Watergate over which President Nixon resigned, and other social movements resulted in an increasing distrust of government, politicians, and traditional institutions. People questioned authority. The women's movement, disabilities and mental illness movements became transnational, showing up in UK, Europe, Canada, and Australia, among other places.

In medical sociology in the late 1970s and early 1980s Marie Haug and colleagues (Haug \& Lavin, 1983) investigated the public's and patient's attitudes toward challenging their physician's authority in a medical encounter. People thought that they had a right to know the information in their medical records and some would disregard their physician's treatment orders under some conditions. In retrospect these findings seem like minor challenges, especially since they have now been incorporated into patient's Bill of Rights (Weitz, 2004).

Much more dramatic were the successes of the women's health movement in the 1960s and 1970s, and later the AIDS and breast cancer movements. Women created "C-R groups" (consciousness-raising groups) which became the symbol and tactic of women's liberation (Morgen, 2002, p.4) - small C-R groups sprang up that were self-help/mutual aid groups although not identified as such (Borkman, 1975). Radicalized women demanded more knowledge about their bodies, invented collectives-democratically run health clinics, to have 
control over their health care-and protested patronizing and humiliating gynaecological procedures, among other things (Morgen,2002).

In the early 1980s when HIV/AIDS was evolving as a major killer of gays, the uncertainty and urgency of people who were fighting for their lives (Chambré , 2006) underlay much of the early invention and creativity in developing services such as buddy services, hotlines, and hybrid organizations that provided services and advocacy.

The epitome of medical sovereignty and control is in the area of knowledge production or medical research and clinical treatment decisions (Starr, 1982). Lerner (2001) chronicles the conflict in the 1960s among women patients and physicians treating breast cancer. Pressured by female patients in conjunction with evidence from new randomized controlled clinical trials finally convinced physicians to change their treatments. AIDS activists (Epstein, 1996) directly challenged scientific knowledge and there search process and were successful in modifying the rules, timing, and conduct of drug trials and obtaining representation on scientific decision-making boards.

Recently, several publications have brought together the knowledge of these individual movements in health with the theory and knowledge of social movements resulting in Social Movements in Health, edited by Phil Brown and Stephen Zavestoski which points out that "Previous research has focused on individual cases of health social movements: we consider them as a collective group that when taken together have been an important force for social change" (Brown \& Zavestoski, 2005, p.2).

In the UK parallel movements have taken place. The recently emerging health social movements (HSMs) are distinguished by the focus on people with diseases or health conditions and their understanding and personal experiences of illness (Brown \& Zavestoski, 2005, p.3). Often the movements are motivated in part by the incongruity between the individual's experience of illness and the official system of diagnosis and treatment of that disease. (Hess, 2005, p.18). The embodied health movements are challenging scientific knowledge and authority in extensive and fundamental ways; these include:

1. Questioning disease causation;

2. Confronting inadequate treatment options;

3. Criticizing strategies of prevention;

4. Challenging research funding priorities;

5. Advocating participation in policy making; and

6. Creating non-stigmatizing and constructive identities

A volume titled Consuming Health: The Commodification of Health Care (Henderson \& Petersen, 2002) focuses on theoretical perspectives and research on empirical manifestations of consumerism and its limits (e.g., in [Australian] hospitals-(Henderson,2002) or living with chronic heart failure [in Scotland]-(Reid \& Clark, 2002)).

In the recent volumes on consumerism in health (Brown \& Zavestoski, 2005; Henderson \& Petersen, 2002), the writing is usually generalized and without a country context as if Australia, Britain, Canada, Norway, the United States, or other western democracies were alike (or their differences not worth noting). Titles give no country location; literature reviews and theory sections are couched in universalistic language-the reader being implicitly invited to infer that country location is irrelevant. Our research experience studying SHOs in health care systems of Sweden, UK, and USA convince us of the opposite-country is very relevant.

This chapter is distinctive in two ways:

1. We assume that theoretical perspectives on consumerism in health are not universally applicable to all Western democratic countries but their usefulness in various contexts needs to be determined. We speculate or hypothesize that British and US differences in health care systems and voluntary sectors, among other 
factors shape or influence the nature of contributions that SHGs/SHOs make to health consumerism.

2. Instead of research on the macro or national level embodied health movements, we consider unrecognized research on meso or community level SHGs and SHOs. We show that similar challenges to scientific and professional knowledge, advocacy for participation in policy-making, and other innovations are occurring on the community or meso level.

While there are many unaddressed issues in consumerism in health, a major dividing line seems to be between the relatively modest meaning of "freedom of choice," "right to know," and "entitled to participate" (usually referring to patients selecting from among options provided by the health care system) and the more extensive structural changes involved when patients or consumers challenge the knowledge, authority, diagnoses, or treatment options (see also Rutherford \& Gallo-Cruz, 2008, in this book). It is with these latter, more extensive changes upon which this chapter is focused.

\section{Characteristics of Health Care Systems and the Voluntary Sectors of Society}

The US and UK, both western industrialized democracies, have been characterized as individualistic (US) and a post-welfare state (UK). UK refers to the United Kingdom which is comprised of England, Scotland, Northern Ireland and Wales.

These two Western democracies have very different health care systems and similarly strong but varying voluntary sectors. The major structural dimensions of the health care system are described in Table1. A national health care system has been in existence in the UK since 1948 which is based on the concept of positive rights: governments and others incur obligations "to provide those goods and services necessary for each individual to exercise her/his rights" (Blank \& Burau, 2004, p.19). In contrast, the individualistic US is characterized by negative rights. With negative rights obligations are imposed on government and others not to interfere with the rights bearer. "They relate to the freedom to be left alone to use one's resources as one sees fit. Under negative rights, each person has a sphere of autonomy that others cannot violate... The only claim on others is a freedom from intrusion" (Blank \& Burau, 2004, pp.18-19).

\begin{tabular}{|c|c|c|}
\hline Dimension & United States & United Kingdom \\
\hline Citizen rights to health care? & Negative rights & Positive rights \\
\hline Individual relates to society? & Individualistic & Egalitarian \\
\hline Nature of system & $\begin{array}{l}\text { Mixed and fragmented: } \\
\text { Free market with } \\
\text { governmental insurance } \\
\text { for special vulnerable } \\
\text { populations }\end{array}$ & $\begin{array}{l}\text { Centralized with a national } \\
\text { health system }\end{array}$ \\
\hline Role of free market & Very high & Low but rising \\
\hline Payment for care & $\begin{array}{l}\text { Mixed: Government } \\
\text { through taxes, private } \\
\text { insurance, out-of-pocket }\end{array}$ & $\begin{array}{l}\text { Government through general } \\
\text { taxes }\end{array}$ \\
\hline $\begin{array}{l}\text { Extent health system publicly funded } \\
\text { (2004) }\end{array}$ & $44.7 \%$ & $86.3 \%$ \\
\hline Universal coverage & No & Yes \\
\hline $\begin{array}{l}\text { Ownership of facilities (hospitals, nursing } \\
\text { homes, etc.) }\end{array}$ & $\begin{array}{l}\text { Mixed: private for-profit, } \\
\text { non profit, government }\end{array}$ & Predominately government \\
\hline $\begin{array}{l}\text { National policy on consumers } \\
\text { involvement in health care system }\end{array}$ & $\begin{array}{l}\text { No; variable policies for } \\
\text { different diseases, } \\
\text { government jurisdictions, } \\
\& \text { myriad of health } \\
\text { insurance companies }\end{array}$ & $\begin{array}{l}\text { Yes - consumers involvement } \\
\text { mandated }\end{array}$ \\
\hline
\end{tabular}


The UK's national health care system is based on the government providing care for all citizens. In contrast, the US has a mixed system with the market economy a central player along with governmental insurance for special populations (Medicaid, Medicare, Veteran's care, and public health facilities on state and county levels). The mixture includes many forprofit health insurance companies, self-insured health insurance of large corporations or labor unions, and non-profit health care insurance plans and providers. In the UK, the government pays health care costs through general taxes while in the US health care is funded by a mixture of private for-profit health insurance paid by employees and the organizations which employs them, government through general taxes, and consumers out-of-pocket. All citizens have health care coverage in the UK but access is limited in the US -more than 40 million Americans reported they did not receive needed health care services because of lack of health insurance (Weitz, 2004). Similarly with regard to ownership of facilities, the UK's facilities are owned predominately by the government and the US has a mixed system with some government facilities as well as extensive involvement of the non-profit and for-profit health insurance companies, hospitals, and nursing homes.

The UK's national health system has adopted a national policy requiring that consumers be involved in various aspects of the planning, development, delivery, and evaluation of services (DH, 1990, 2003). Although this policy has not yet been uniformly adopted across all conditions and diseases, the exemplars of consumers involvement in many aspects of service are in the field of mental health (Halliday \& Sherwood, 2003).

The UK has adopted a national policy requiring that consumers be involved in all aspects of the nation's centralized national health system (DH, 1990, 2003); although this is not yet uniform across all diseases or conditions, there are examples from the mental health field of consumers being involved in all aspects of service delivery and development. (Halliday \& Sherwood, 2003). The US has no national policy; instead, each disease area or silo has its own answer to the extent and ways in which it engages consumers. Some state-level policies are found where there are funded programs in mental illness, the developmentally delayed, and other disabilities.

The United States spends much more on health care per individual and as a percentage of GDP than the UK and generally has more high technology equipment, but health outcomes based on globally accepted indicators of life expectancy and infant mortality rates are lower (Table 2). Analysts attribute some of the extensive costs of the US system to the negative rights approach and the fact that adequately insured consumers expect extensive high technology equipment and expensive end-of-life care. Meanwhile, the uninsured lack even rudimentary prenatal care (Blank \& Burau, 2004). In contrast, UK is known among European health systems for having the most efficient use of financial resources (Blank \& Burau, 2004). 


\begin{tabular}{|c|c|c|}
\hline Dimension & United States & United Kingdom \\
\hline $\begin{array}{l}\text { \$ spent on health care per capita (Intl dollars } \\
2004)^{\mathrm{a}}\end{array}$ & $\$ 6,096$ & $\$ 2,560$ \\
\hline Health care: Percent of GDP $(2004)^{a}$ & $15.4 \%$ & $8.1 \%$ \\
\hline Life expectancy at birth $(2005)^{\mathbf{a}}$ & $\begin{array}{l}\text { Male } 75 \\
\text { Female80 }\end{array}$ & $\begin{array}{c}\text { Male } 77 \\
\text { Female } 81\end{array}$ \\
\hline Infant mortality (per 1,000 live births 2005$)^{\mathbf{a}}$ & 7 & 5 \\
\hline MRI units per million population (1995) ${ }^{\mathbf{b}}$ & 7.3 & 3.4 \\
\hline Patient choice of doctors ${ }^{b}$ & $\begin{array}{l}\text { Extensive, except } \\
\text { some HMO's }\end{array}$ & $\begin{array}{l}\text { Restricted: Sign up } \\
\text { with GP in area }\end{array}$ \\
\hline $\begin{array}{l}\text { Primary care physician is gate-keeper to } \\
\text { specialists }^{\mathbf{b}}\end{array}$ & $\begin{array}{c}\text { Mixed: Some } \\
\text { insurance yes; MDs } \\
\text { averse to being gate- } \\
\text { keepers }\end{array}$ & $\begin{array}{c}\text { Yes: GP gate- } \\
\text { keeper to specialist } \\
\text { MD }\end{array}$ \\
\hline $\begin{array}{l}{ }^{2} \text { World Health Organization (2007). } \\
\text { } \text { Blank and Burau(2004). }\end{array}$ & & \\
\hline
\end{tabular}

When policy analysts examine health care systems from the broadest perspective, very little about patient/consumer choice is mentioned. The major variables they discuss are governments (their policies and funding); health care professions, especially physicians; the free market economy of corporations, hospitals, health insurance companies, and pharmaceutical companies; the non-profit sector; and, issues of control, costs, and policies (Tuohy, 1999; Blank \& Burau, 2004; Light, 2000). When changes in medical authority are analyzed by sociologists, the erosion in medical authority is not regarded as being due to patient/consumer choices or increasing consumer authority, but to shifts in financing and other policies by governments or strategies of the free market economy (Tuohy, 1999; Light, 2000). In these broad system-wide analyses of health care systems, consumer choice is viewed as important in whether or not health care systems allow consumers to choose their physician at initial point of contact and whether or not the initial point of contact is a gatekeeper to consumer's access to specialist physicians. US consumers are more likely to have a choice in their physician; UK consumers choices are very restricted -they have to sign up with in the limited choices of GPs (general practitioner) available within their geographical area. Further, in the UK the GPs act as gatekeepers by referring consumers to specialists whereas in the US physicians are averse to this gate-keeping role although they are required to do it in some health insurance plans.

\section{The Voluntary Health Sector}

An international study of the non-profit sector in a number of industrialized countries, known as the Johns Hopkins Comparative Nonprofit Sector project, was conducted in the late 1990s. US and UK were included among the 12 countries studied so direct comparisons can be made since standardized methodologies were used in all 12 countries. Researchers concluded that the differences in size among the voluntary sectors in US and UK were minor (Salamon \& Anheier, 1996) but the composition of the sectors varied considerably. Education, healthcare, and social services sectors' share of the non-profit sector operating expenditure was $57 \%$ in Britain but $85 \%$ in US (Salamon \& Anheier, 1996). Looking solely at health care, the voluntary sector operating expenditure was $52.67 \%$ in US and $3.5 \%$ in UK. Instead, UK's voluntary sector spends extensively on education and research (42\%) and culture and recreation (20.2\%).

An important and often forgotten part of the informal voluntary sector are SHGs and SHOs. We define SHGs as "autonomous, voluntary assemblies of people in similar situations or predicaments, or with the same disease or condition, who join together to cope with and resolve their troublesome issue through sharing knowledge and providing mutual social and emotional support" (Borkman, 2004, p.428). Important to the definition is that SHGs are 
governed by and for the people with the shared experience, not by professionals or outsiders. SHOs are more formal than SHGs and often are "paid staff non profits" (Smith, 2000) -they are usually registered $501(\mathrm{C}) 3 \mathrm{~s}$ (in the US) or charities (in UK) with budgets and goals to provide services to their peers but they use self-help/mutual aid approaches (Borkmanetal, 2005). SHGs are usually too informal to be counted in tallies of voluntary organizations since they are not on tax rolls.

Service-user groups (UK) are like SHGs/SHOs in that they are voluntary assemblies of people with the same condition or disease but differ in that they tend to be advocacy or lobbying groups or formed specifically to comment on a specific service (e.g. in a locality) and do not necessarily provide emotional support, information, or develop collective experiential knowledge (Table3).

Table3. Characteristics of Self-Help and Advocacy Groups in US and UK.

\begin{tabular}{|c|c|c|}
\hline Dimension & United States & United Kingdom \\
\hline $\begin{array}{l}\text { Percent population attend SHG per } \\
\text { year }^{a}, \text {, }\end{array}$ & $4 \%-7 \%$ & $4 \%$ \\
\hline Number of $12^{\text {th }}$ step SHGs ${ }^{a}$ & $1 / 3$ of groups & Minor $^{c}$ \\
\hline 12-step SHGs impact on society & $\begin{array}{l}\text { Major part of popular } \\
\text { culture }\end{array}$ & Minor \\
\hline University research on SHGs & Moderate & Minimal \\
\hline $\begin{array}{l}\text { Proportion of SHGs to official treatment } \\
\text { units }^{d}\end{array}$ & $\begin{array}{c}\text { More SHGs in } \\
\text { alcoholism \& in mental } \\
\text { illness }\end{array}$ & Fewer \\
\hline Service-user advocacy groups & Few & Many \\
\hline University research on service-users & Little & Extensive \\
\hline \multicolumn{3}{|c|}{$\begin{array}{l}\text { a Wuthnow (1994) and Kessler, Mickelson, and Zhao (1997). } \\
\text { b Elsdon, Reynolds, and Stewart (2000) estimates that one in } 25 \text { of the population belong to a SHG in United } \\
\text { Kingdom. } \\
\text { c Numbers of 12-step groups are not collated in United Kingdom. } \\
\text { d Goldstrom et al. (2006), SAMSHA (2006), and Room and Greenfield (1993). }\end{array}$} \\
\hline
\end{tabular}

\section{National and Community Levels of Social Change and Consumer Transformation}

The contribution of SHGs and organizations to consumerism in health is found on two levels. First, SHGs contribute to national social movements: Relatively well documented is the importance of SHGs/SHOs to national level health movements. The typical process is that SHGs of concerned patients with disease $X$ meet together to share their experiences of living with the disease; so on collective knowledge is created about what they need in daily living, deficiencies in their medical treatment or issues with unresponsive and inadequate health care system that leads to their empowerment as advocates for changes in the system. Often advocacy groups are created or the SHG becomes an advocacy group. Often elements of self-help/mutual aid are retained or reinstituted in the advocacy organizations to provide moral and emotional support and bolster new identities (the complexities of this process are theorized in Borkman, 1999). As a case in point, Into Our Own Hands (Morgen, 2002) chronicles the SHGs of women who learned about their bodies and appropriated the knowledge for women which culminated in the now-classic volume Our Bodies, Ourselves: $A$ Book by and for Women (The Boston Women's Health Book Collective, 1971) which has become an icon of the women's health movement. Also see Chambré's (2006) discussion of SHGs and support groups for AIDS patients and Lerner's (2001) discussion of the SHG Recovery, Inc. for breast cancer (see Sulik \& Eich-Krohm, 2008; Bourgeaultetal, 2008 in this volume for a critique of how national level social movements run the danger of incorporation and individualization by neo-liberal policy making and the established medical systems). 
Second, the community level of social change and consumer transformation made by SHGs/SHOs in the US and UK has not been recognized. We present four brief case studies based on published research to illustrate the kinds of changes SHGs/SHOs make at the meso level to both individual and collective change as well as their potential to impact the wider communities and services in which they are located (Table 4).

\section{Case 1: Personality Disorder}

The context for this 1999 study was that people labelled with personality disorder (PD) were not able to gain services for the diagnosis although they might receive services for other concurrent diagnoses, such as depression. The PD diagnosis was a "catchall" label with little scientific credibility, widely believed to be untreatable, and appeared to be a pejorative judgment rather than a clinical diagnosis (Lewis \& Appleby, 1988). During the 1990s a number of people with PD diagnosis sought advocacy from a local branch of MIND, a national voluntary organization in the UK. Their experiences spanned the gamut from losing their children, being sent to psychiatric hospitals (hospitals for people with mental illness) to being denied mental health services. The UK Home Office had also developed policy proposals for managing people with a severe PD if they were deemed to be dangerous to the publicregardless of whether this was related to a deterioration in their clinical state-which included potential removal to special units.

A group of people with PD diagnosis formed a research partnership managed by Castillo, an advocate at the local MIND branch, and supervised by academic social scientists and funded by the local University. Castillo and the group developed a model of participatory research putting experiential knowledge at its center (Castillo, Allen, \& Coxhead, 2001). Five of the original service-user group were trained as researchers and interviewed 50 people with PD diagnosis in the local area.

The results were groundbreaking. Common threads of childhood abuse and trauma were uncovered that were unknown to the medical model. The research was published extensively in national journals and the team presented at 18 professional conferences. Their questions and resulting findings provided credible empirical evidence of their collectively experientially based interpretations and contributed directly to national developments in the UK which now has developed services for people with this diagnosis

\begin{tabular}{|l|l|l|}
\hline Table4. Challenges to Medical Authority Made by Self-Help Groups \\
\hline Name of Group & Type IIIness or Condition & $\begin{array}{l}\text { Challenges to Medical or } \\
\text { Popular Authority }\end{array}$ \\
\hline 1. Personality disorder & Mental illness: UK & $\begin{array}{l}\text { Service-user research challenged } \\
\text { (untreatable) psychiatric diagnoses } \\
\text { \& identified (treatable) condition to } \\
\text { obtain medical care; advocacy }\end{array}$ \\
\hline 2. Carers & Caring for family member: UK & $\begin{array}{l}\text { Reject popular idealistic views of } \\
\text { caring; more realistic expectations; } \\
\text { local advocacy to improve services }\end{array}$ \\
\hline People who stutter & Speech disorder: US & $\begin{array}{l}\text { Self-blaming "victims" evolve to } \\
\text { empowered critics of professional } \\
\text { therapies; change of meaning } \\
\text { perspective and identity; } \\
\text { advocacyt o prevent stuttering and } \\
\text { change research priorities }\end{array}$ \\
\hline $\begin{array}{l}\text { 4. GROW adapted 12 step } \\
\text { group }\end{array}$ & Mental illness: US & $\begin{array}{l}\text { Role of ex-mental patient shed; } \\
\text { normalized identity as member of } \\
\text { "caring and sharing" community }\end{array}$ \\
\hline
\end{tabular}




\section{Case 2: Carers}

The official definition of a carer in UK is someone who cares, unpaid, for a relative, partner, or friend or for a child because of disability, illness, or frailty $(\mathrm{DH}, 1998)$. At the time of the study there were 5.7 million informal carers in the UK-one in eight adults, nearly as many men as women (42\% and $58 \%$ respectively). In the UK there has been a national carers movement (Barnes,1997) which has raised awareness about the personal and health consequences of providing long-term care and this lobby has contributed health and social policy initiatives such as the Carers (Recognition and Services) Act ( $\mathrm{DH}, 1995)$ and The National Carers Strategy $(\mathrm{DH}, 1999)$. While health care is free in UK and welfare benefits are available for both the carer and the person they care for, the carers lobby has drawn attention to the inadequacy of existing benefits and social care services.

In the study (Munn-Giddings, 2003) of two SHGs, data were drawn from two taped sessions with each group as well as semi-structured interviews with 15 active members (who regularly attended meetings) and five inactive members who only received the newsletters. A significant finding was that inactive members' views on caring varied little from the dominant understandings and established literature (e.g., Finch, 1989). In contrast active members appeared to have undergone a subtle, but powerful, reinterpretation of their situations. Over time, they appeared to adjust their expectations in the light of empathetic and experiential exchanges with others. Their measure of being a (good enough) carer was in comparison with others in the group rather than to an abstract ideal.

Analysis revealed that it was the process of sharing and exchanging stories that made it possible for active members to share their coping strategies and to expose their difficulties (Munn-Giddings \& McVicar, 2007). They found it difficult to expose their vulnerabilities even to sympathetic professionals and supportive family members were thought either not to fully understand the situation or had to be shielded from reality.

The carers groups implicitly challenged the conventional wisdom and through sharing their experiences confronted the realistic boundaries of their energy. They also realized the lack of governmental support to sustain them and became quiet advocates with local health and social care authorities to improve the support they received.

\section{Case 3: People who stutter - from self-blaming "victim" to critic of stuttering therapy}

This case study is based on Borkman's (1999, Chapters 5 \& 6) longitudinal study of a SHG, the Caring Group for Stutters (pseudonym), which evolved over 10 years. The group began as a fragile collection of unselfconfident self-named "stutterers" and evolved into a mature organization of "people who stutter" who had reframed their stuttering and the results of therapies based on hundreds of attendees' testimonies.

The research relied on a variety of methods to collect and analyze data: participant observation of the group was done intensively for two years and less intensively for the following six years; periodic in-depth interviews were conducted with officers and leaders over the period; analysis of newsletters and other organizational documents were made; and two mail questionnaire surveys of attendees and of organizational functioning were done (see Borkman, 1999, p.218).

The group began with the implicit goal of finding a cure for stuttering. A core of highly motivated members led the group while others attended, left, and/or returned. Attendees recounted their narrative of the types of therapies they had had (frequently, two or more) and the results: many stuttering therapies produced short term fluency of three or more months, but the individual then returned to his/her pre-therapy level of stuttering. They consistently attributed the therapy's failure to themselves. Over a period of several years, through the sharing of hundreds of experiences, a common understanding emerged of the serious limitations of stuttering therapies and that most commercialized "cures" were quacks. Reviewing the scientific research on stuttering from their experiential perspective, they 
realized no cure had been found. Note that it was only after developing confidence that their personal experiences with stuttering therapy constituted valid knowledge could they accept the reframing from stuttering being a personal deficiency to viewing it as a deficiency in the therapy per se.

With their reframed knowledge and research review of stuttering in children, they held public education sessions for parents advising them against therapy in order to prevent adult stuttering. From their experiential perspective, they reviewed and found major gaps in stuttering research funded by the National Institutes of Health $(\mathrm{NIH})$ and became advocates challenging NIH to redress them. Finally, with their experiential expertise combined with a new consciousness from the rising disability movement (Charlton, 1998) they rejected the label of stutterer and referred to themselves as people who stutter: their speech handicap was but a part of the person.

\section{Case 4: Grow - from ex-mental patient to respected member of "a caring and sharing" community}

Community psychologists Julian Rappaport and Edward Seidman and their students (Rappaportetal.,1985) developed a collaborative research relationship with GROW, a selfhelp/mutual aid group for the mentally ill. Founded in Australia by previous mental patients, it was imported to Illinois in 1978; a decade later there were about 100 groups in Illinois. Using an adapted 12 step program, GROW holds weekly meetings, has official literature and creates "a caring and sharing community" with social gatherings, contact assignments, and friendships (Salem, Seidman, \& Rappaport, 1988).

Professors Rappaport, Seidman, and their various students used a longitudinal study design to identify changes in individual member's psychological and social functioning over a 27 month period and a repeated cross-sectional design to periodically study meetings and the organization. Participant observation of over 500 meetings was in 15 locations in Illinois and over 300 individuals were interviewed from 2 to 8 hours and various measures of organizational climate, cohesion, and growth were taken. By the early 1990s GROW research was the subject of multiple graduate student dissertations and of publications in professional journals (e.g., Robertsetal., 1999; Salem et al.,1988; Kennedy \& Humphreys, 1994).

GROW has a community narrative about its members, their identity, and potential. The "caring and sharing community" of givers as well as receivers provides hope and a sense of their own capacity for positive change (Rappaport, 1993, p.245). Members' personal stories were often consistent with the community narrative. Members were less likely than their equivalents with similar histories of mental hospitalization to be rehospitalized (Rappaport, 1993). Rappaport who had studied chronic mental patients for decades did not find the typical emphasis on defining oneself as sick, being dependent on medications to control behavior, or longing to live an independent but lonely life. Instead, GROW members had many examples from their peers who had recovered and defined themselves differently. GROW members continued to use medication but did not see it as central to their selfdefinition. GROW members who were well into recovery had shed their internalized-societal view of the stigma of mental illness, no longer defined themselves as mentally ill and had selfimages of being valuable and worthwhile. (Kennedy \& Humphreys, 1994, p.190). Rappaport concluded that the mutual help organization

is a normative structure in social experience-not unlike families, religious organizations, political parties, labor unions, professional organizations, or other voluntary associations. Members are not clients receiving services and therefore somehow different from the rest of us; rather, they are people living lives. Professional treatment is not necessarily the appropriate comparison group if one wants to understand such experiences. (Rappaport,1993,p.246) 
The group transformed persons labelled as mentally ill who were primarily consumers of health care to persons with positive and non-stigmatized identities who were members of a "caring and sharing community."

\section{Conclusions}

The US and UK share the phenomena of SHGs/SHOs; the peer led and owned nature of both is common in each country. In both countries SHGs/SHOs have contributed to social change and a broadened consumer "voice." SHGs/SHOs are embodied (Brown \& Zavestoski, 2005, p.3) change agents in which the participants base their problem solving on their personal experiences of illness or conditions. In the Introduction we listed six issues identified in the national embodied social movements (see p.131) of greater consumer empowerment.

Examining the case studies, we identify which of the issues are illustrated in each case; this is presented in Table 5.

Thus, as is evident in Table 5, our cases illustrate all of the six issues of consumer challenges to medical authority indicating that local SHGs are confronting issues similar to the national level social movements, albeit on a smaller scale.

How do the health care systems shape the SHGs and SHOs? The major characteristics of the US health care system in this context are its mixed and decentralized nature, the lack of national policy on consumer decision-making in the health care system, and the extensive involvement of the voluntary sector in health care. How do these characteristics influence the reactions of SHGs in our case studies?

In the UK's centralized system with a national mandate for service user/consumer involvement, our cases illustrate that:

Case 1 - Personality disorder illustrates that the policy on consumer involvement encourages self-advocacy even in areas (disease causation) which had previously been regarded as the sole province of professional physicians.

Case 2-Carers revolved more on popular notions of carers than to professionalized views within the health care system but showed that local SHGs can evolve into lobbying groups especially since and when there are local level units of the national health system available to hear their complaints. (In the US, such local groups might not have any local health authorities with jurisdiction to do anything about their grievances).

In the US's mixed, decentralized, and fragmented system that has no national policy on consumer involvement but an extensive participation of the voluntary sector in health care has arisen in various silos, our cases illustrate that:

Case 3-People who stutter-local SHGs can raise the consciousness and transform individuals from being "victims" to experientially knowledgeable non-stigmatized persons and the local SHGs can evolve into organizations with advocacy goals such as educating peripheral groups (parents of children who stutter) and criticizing research priorities of federal agencies.

Case 4-GROW, the 12-step based group that attracts people with mental illness diagnoses, illustrates that SHGs/SHOs can develop alternative and de-stigmatized meaning perspectives and identities to serious mental illness. 


\begin{tabular}{|l|l|}
\hline \multicolumn{2}{|l|}{ Table 5. Self-Help Groups Challenge of Medical Authority. } \\
\hline Consumer Challenges to Medical Authority & SHGs That Illustrate the Issue \\
\hline 1. Questioning disease causation & Case 1: Personality disorder-UK \\
\hline 2. Confronting inadequate treatment options & $\begin{array}{l}\text { Case 1: Personality disorder-UK } \\
\text { Case 3: People who stutter-US }\end{array}$ \\
\hline 3. Criticizing strategies of prevention & Case 3: People who stutter-US \\
\hline 4. Challenging research funding priorities & Case 3: People who stutter-US \\
\hline 5. Advocacy to participate in policy making & $\begin{array}{l}\text { Case 1: Personality disorder-UK } \\
\text { Case 2: Carers-UK }\end{array}$ \\
\hline $\begin{array}{l}\text { 6. Creating non-stigmatizing and constructive } \\
\text { identities }\end{array}$ & $\begin{array}{l}\text { Case1: Personality disorder-UK } \\
\text { Case 3: People who stutter-US } \\
\text { Case 4: Grow-US }\end{array}$ \\
\hline
\end{tabular}

GROW also illustrates the high prevalence of 12-step SHGs in the US. Even though Australia is culturally and politically closer to the UK than it is to the US, GROW was successfully imported into US probably because of the fertile and extensive environment of 12-step based SHGs here.

Recovery identities that are non-stigmatized, de-medicalized (Conrad \& Schneider, 1992), and anonymous are an integral part of US culture due to the long and strong influence of AA and other 12-step recovery (Room, 1992); GROW could build on this tradition.

The UK's national policy of consumer involvement in decision-making in health is exhibited in ways other than have been shown in our cases. Thus:

1. There is a policy of "expert patients" (DH, 2006) modelled on the Stanford Chronic Disease course (Lorig, 1982) which provides group based support for people in the management of their long term condition led by peers with the same condition and which now includes carers. The program is for all age groups; over 1,400 volunteer peer tutors are currently involved.

2. Involving service users in planning, providing, and evaluating education and training has been advocated in national health and social care policies since the late 1990s. For example, in 2003 UK universities were required to change the programmes they were delivering for the training of social workers by involving experiences consumers/expert patients and carers in all aspects of the course including the selection, teaching, and assessment of students, design and review of the degree, and preparation for and provision of placement (DH, 2002,p.9).

3. A distinctive language of "service-users" has developed that is widely used in policy, practice, and academic writing that specifically replaces the term "consumer."

4. On a national level, United Kingdom appears to be developing a health consumer movement (Allsop, Jones, \& Baggott, 2005; Allsop, Baggott, \& Jones, 2002) of which SHGs are a part

We propose that the national health policy mandating the engagement of service users or consumers in the policy process is both responding to and facilitating this social movement in the UK. There are concerns that incorporating consumers into main stream services can both inhibit dissent and lead to "professionalized consumers" who do not necessarily represent the views of the wider consumer group. The key question is whether these measures lead to genuine power sharing in decision-making or to tokenism. 
In contrast, in the US, there is no coherent health consumer movement. SHGs/SHOs appear to occupy both a role and space outside the main health care system. While forming links with local sympathetic health professionals (see GROW), meso level groups and organizations have limited opportunities to impact main stream health policy and practice. Only the larger national social movements have been successful in this way. In this sense SHGs/SHOs remain an alternative form of health resource for consumers to "choose." Interestingly, in two major areas, treatment for alcoholism and for mental illness, more services are provided by SHGs/SHOs than by mainstream professionals (Goldstrom et al., 2006; Room \& Greenfield, 1993; SAMSHA, 2006). These figures appear to be well kept secrets as mainstream services seem oblivious to the high prevalence of SHGs/SHOs providing services alongside them; this is an indirect indicator that SHGs/SHOs are outside and separate from the mainstream system.

What is important to note is that while similarities and distinctions can be discerned in the global health movements, the distinctive nature of national health systems and policies enable and constrain the forms that SHGs/SHOs are likely to take. Dill and Coury (2008) in "Forging a new Commons:Self Help Associations in Slovenia and Croatia" in this volume found that SHGs/SHOs in post-Communist Yugoslavia (now Slovenia and Croatia) were not only less independent from the state but they also cultivated this dependence, among other differences, from their equivalents in US and Europe which were attributed to the societal context of transition to capitalism with an emerging voluntary sector.

\section{How Do These Findings Contribute to Consumerism Theory in Health?}

Two strands of theoretically based material seem relevant to our findings: First, the "consumerist model" with its implied limitation and baggage of "patient choice" seems inadequate conceptually to support the extensive and systemic changes in patient/serviceuser involvement in decision-making occurring in the British health care system. Croft and Beresford (1993) propose an expanded model-the consumerist versus the democratic approaches to involvement. The consumerist model focuses on the patient as a consumer gaining information and obtaining better managed services within the status quo context of professional dominance. In contrast, the democratic model views the "patient" as a citizen or service-user with rights to participate in decision-making and to be an advocate for changes in the system. These distinctions seem more applicable to the UK health care system than to that of the US.

Second, the activism of patients and citizens in SHGs and SHOs that challenge the frameworks, diagnoses, and treatments of medical professionals is on a community or meso level rather than the national macro-level. People that share a common health condition find through their participation in SHGs/SHOs a voice to challenge the prevailing medical or popular view of their condition when their lived experience does not match the model presented by medicine or the culture. Retaining the emphasis on collective community activities (the wellspring of many national movements) reminds us of the importance of grassroots peer led collective action that gives participants the opportunity to be both providers as well as consumers of services (see Greenspan \& Handy, 2008; Staples \& Stein, 2008, in this book). The SHGs/SHOs are advocating or living social change, but we have lacked conceptualizations of community-level social changes. A new book begins to fill in this gap: From the Bottom Up: Grassroots Organizations Making Social Change by Carol Chetkovich and Frances Kunreuther (2006) which describes 16 small locally-based grassroots organizations that are making systemic and structural changes in their communities.

In summary, we have preliminary evidence from this chapter and from Dill and Coury's (2008) chapter in this volume that the health care system and the voluntary sector of a country constitute a context that impacts the activities and outcomes of SHGs/SHOs and of consumer participation in policy making. Despite many similarities in SHGs in the UK and US, there are major differences in consumer participation in health care policy and we suggest that analysts who write in universalistic terms as if the country and its health care system were irrelevant are on shaky ground. 


\section{Acknowledgments}

We appreciate the constructive suggestions that improved the chapter made by the editors Susan M. Chambré and Melinda Goldner. Aina Stunz's incisive editing helped focus and sharpen our arguments in a concise and beneficial manner.

\section{References}

Allsop, J.,Baggott, R., \& Jones, K. (2002). Health consumer groups and the national policy process. In:S. Henderson \& A. Petersen (Eds), Consuming health: The commodification of healthcare (pp. 48-65). London: Routledge.

Allsop, J., Jones, K., \& Baggott, R. (2005). Health consumer groups in the UK: A new social movement? In: P. Brown \& S. Zavestoski (Eds), Social movements in health (pp. 5776). Malden, MA: Blackwell Publishing Ltd.

Barnartt, S., \& Scotch, R. (2001). Disability protests: Contentious politics 1970-1999. Washington, DC: Gallaudet University Press.

Barnes, M. (1997). Private lives and public policy: The self-organisation of carers in care, communities \&citizens. Harlow: Longman.

Baudrillard, J. (1998). The consumer society: Myths \& structures. Thousand Oaks, CA: Sage.

Blank, R. H., \& Burau, V. (2004). Comparative health policy. England: Palgrave Macmillan.

Borkman, T. (1975). Changing sex roles: Consciousness-raising groups as a vehicle of adult resocialization. In: J. Williams, A. Schwartzbaum \& R. Caney (Eds), Sociological research symposium V (pp.296-300). Richmond, VA: Virginia Commonwealth University.

Borkman, T.(1999). Understanding self-help/mutual aid: Experiential learning in the commons. New Brunswick, NJ: Rutgers University Press.

Borkman, T. (2004).Self-help groups. In: D. F. Burlingame (Ed.), Philanthropy in America: A comprehensive historical encyclopedia (Vol. 2, pp.428-432). Santa Barbara, CA: ABC-Clio.

Borkman, T., Karlsson, M., Munn-Giddings, C., \& Smith, L. (2005). Self-help organizations and mental health: Case studies of mental health self help organizations in US, England and Sweden. Stockholm, Sweden: Skondal Institute and University.

Boston Women's Health Book Collective.(1971). Our bodies, ourselves: A book by and for women. Boston, MA: New England Free Press.

Bourgeault, I.L., Declercq, E., Sandall, J., Wrede, S., Vanstone, M., van Teijlingen, E., DeVries, R., \& Benoit, C.(2008). Too Posh To Push? Comparative perspectives on maternal request caesarean sections in Canada, the US, the UK and Finland. In: S. Chambré \& M. Goldner (Eds), Advances in medical sociology: Patients, consumers and civil society (Vol.10, pp.99-123). Bingley, UK: Emerald Group Publishing Limited.

Brown, P., \& Zavestoski, S. (Eds).(2005). Social movements in health. Oxford: Blackwell Ltd.

Castillo, H., Allen, L., \& Coxhead, N.(2001).The hurtfulness of a diagnosis: User research about personality disorder. Mental Health Practice, 4(9), 16-19.

Chambré , S.M. (2006). Fighting for our lives: New York's AIDS community and the politics of disease. NewBrunswick, NJ: Rutgers University Press.

Charlton, J. (1998). Nothing about us without us: Disability oppression and empowerment. Berkeley, CA: University of California Press.

Chetkovich, C., \& Kunreuther, F. (2006). From the bottom up: Grass roots organizations making social change. Ithaca, NY: ILR press, an imprint of Cornell University Press.

Conrad, P., \& Schneider, J.W. (1992). Deviance and medicalization: From badness to sickness. Philadelphia: Temple University Press.

Croft, S., \& Beresford, P.(1993). Getting involved: A practical manual. London: Open Services Project.

DH -Department of Health.(1990). National Health Service and Community Care Act. London: HMSO.

DH -Department of Health.(1995). Carers (Recognition and Services) Act. London: The Stationery Office.

DH -Department of Health.(1998). Living in Britain: Results from the 1998 General Household Survey. London: The Stationery Office. 
DH -Department of Health.(1999). National strategy for carers. London: The Stationery Office.

DH -Department of Health.(2002). Requirements for social work training. London: The Stationery Office.

DH -Department of Health.(2003). Patient and public involvement. London: The Stationery Office.

DH -Department of Health.(2006). The expert patients programme. London: The Stationery Office.

Dill, A., \& Coury, J.(2008). Forging a new commons: Self-help associations in Slovenia and Croatia. In: S. Chambré \& M. Goldner (Eds), Advances in medical sociology: Patients, consumers and civil society (Vol. 10, pp.247-271). Bingley, UK: Emerald Group Publishing Limited.

Elsdon, K., Reynolds, J., \& Stewart, S.(2000). Sharing experience, living and learning: $A$ study of self-help groups. London: Community Matters.

Epstein, S.(1996). Impure science: AIDS, activism and the politics of knowledge. Berkeley: University of California Press.

Finch, J.(1989). Family obligations and social change. Cambridge: Polity Press.

Goldstrom, I.D., Campbell, J., Rogers, J.A., Lambert, D.B., Blacklow, B., Henderson, M.J., \& Manderscheid, R.W.(2006). National estimates for mental health mutual support groups, self-help organizations, and consumer-operated services. Administration and Policy in Mental Health and Mental Health Services Research, 33(1), 92-103.

Greenspan, I., \& Handy, F.(2008). From discovery to recovery and beyond: The role of voluntary health sector organizations in the lives of women with breast cancer. In: S. Chambré \& M. Goldner (Eds), Advances in medical sociology: Patients, consumers and civil society (Vol. 10, pp.151-176). Bingley, UK: Emerald Group Publishing Limited.

Halliday, M., \& Sherwood, L. (2003). Mental health user/survivor research in UK. A policy briefing. London: Mental Health Foundation.

Haug, M., \& Lavin, B.(1983). Consumerism in medicine: Challenging physician authority. Beverly Hills, CA: Sage.

Henderson, S.(2002). Consumerism in the hospital context. In: S. Henderson \& A. Petersen (Eds), Consuming health (pp.105-120). London: Routledge.

Henderson, S., \& Petersen, A. (Eds).(2002). Consuming health: The commodification of health care. London: Routledge.

Hess, D.J (2005). Medical modernization, scientific research fields and the epistemic politics of health social movements. In: P. Brown \& S. Zavestoski (Eds), Social movements in health (pp.27-30). Oxford: Blackwell Publishing Ltd.

Kennedy, M., \& Humphreys, K. (1994). Understanding world view transformation in members of mutual help groups. In: F. Lavoie, T. Borkman \& B. Gidron (Eds), Self-help and mutual aid groups (pp.181-198). New York: Haworth.

Kessler, R.C., Mickelson, K.D., \& Zhao, S.(1997). Patterns and correlates of self-help group membership in the United States. Social Policy, 27, 27-46.

Lerner, B.H.(2001). The breast cancer wars. New York, NY: Oxford University Press.

Lewis, G., \& Appleby, L. (1988). Personality disorder: The patients psychiatrists dislike. British Journal of Psychiatry, 153, 44-49.

Light, D.W.(2000). The medical profession and organizational change: From professional dominance to countervailing power. In: C. E. Bird, P. Conrad \& A. M. Fremont (Eds), Handbook of medical sociology (5th ed.,pp.201-216). Upper Saddle River, NJ: Prentice Hall.

Lorig, K.(1982). Anatormy of a patient education program: Arthritis self-management. Rehabilitation Nursing, 7(4), 16-20.

Minton, H.L. (2002). Departing from deviance: A history of homosexual rights and emancipatory science in America. Chicago: University of Chicago Press.

Morgen, S.(2002). Into our own hands: The women's health movement in the United States, 1969-1990. New Brunswick, NJ: Rutgers University Press.

Munn-Giddings, C.(2003). Mutuality and movement: An exploration of the relationship between self-help/mutual aid and social policy. Unpublished doctoral thesis, Loughborough University, UK.

Munn-Giddings, C., \& McVicar, A. (2007). Self-help groups as mutual support: What do carers value? Health and Social Care in the Community, 15(1), 26-34. 
Rappaport, J. (1993). Narrative studies, personal stories, and identity transformation in the mutual help context. Journal of Applied Behavioral Science, 29(2), 239-256.

Rappaport, J., Seidman, E., Toro, P.A., McFadden, L.S., Reischl, T.M., Roberts, L.J., Salem, D.A., Stein, C.H., \& Zimmerman, M.A. (1985). Collaborative research with a mutual help organization. Social Policy, Winter, 15, 13-24.

Reid, M., \& Clark, A.(2002). The active citizen works hard: Living with chronic heart failure. In: S. Henderson \& A. Petersen (Eds), Consuming health: The commodification of health care (pp.121-139). London: Routledge.

Roberts, L.J., Salem, D., Rappaport, J.,Toro, P., Luke, A., Douglas, A., \& Seidman, E. (1999). Giving and receiving help: Interpersonal transactions in mutual-help meetings and psychosocial adjustment of members. American Journal of Community Psychology, 27(6), 841-868.

Room, R. (1992). Healing ourselves and our planet: The emergence and nature of a generalized twelve-step consciousness. Contemporary Drug Problems, 19(Winter),717-740.

Room, R., \& Greenfield, T.(1993). Alcoholics Anonymous, other 12-step movements and psychotherapy in the US population, 1990. Addiction, 88(4), 555-562.

Rutherford, M., \& Gallo-Cruz, S.(2008). Selling the ideal birth: Rationalization and reenchantment in the marketing of maternity care. In: S. Chambré \& M. Goldner (Eds), Advances in medical sociology: Patients, consumers and civil society (Vol. 10,pp.7598). Bingley, UK: Emerald Group Publishing Limited.

Salamon, L.M., \& Anheier, H.K. (1996). The emerging nonprofit sector: An overview. Manchester: Manchester University Press.

Salem, D.A., Seidman, E., \& Rappaport, J. (1988). Community treatment of the mentally ill: The promise of mutual-help organizations. Social Work, 33(5), 403-408.

SAMSHA -Substance Abuse and Mental Health Services Administration. (2006). Results from the 2005 National Survey on Drug Use and Health: National Findings. Office of Applied Studies, NSDUH Series H-30, DHHS Publication No. SMA06-4194. Rockville, MD.

Smith, D.H.(2000). Grassroots associations. Thousand Oaks, CA: Sage.

Staples, L., \& Stein, R. (2008). The clubhouse model: Mental health consumer-provider partnerships for recovery. In: S. Chambré \& M. Goldner (Eds), Advances in medical sociology: Patients, consumers and civil society (Vol. 10,pp.177-196). Bingley, UK: Emerald Group Publishing Limited.

Starr, P.(1982). The social transformation of American medicine. New York: Basic Books.

Sulik, G.A., \& Eich-Krohm, A. (2008). No longer a patient: The social construction of the medical consumer. In: S. Chambré \& M. Goldner (Eds), Advances in medical sociology: Patients, consumers and civil society (Vol. 10,pp.3-28). Bingley, UK: Emerald Group Publishing Limited.

Tuohy, C.H.(1999). Accidental logics: The dynamics of change in the health care arena in the United States, Britain, and Canada. New York, NY: Oxford University Press.

Weitz, R.(2004). The sociology of health, illness, and health care: A critical approach (3rd d.). Belmont, CA: Wadsworth/Thompson Learning.

World Health Organization. (2007). Countries data and statistics. Accessed on February 24, 008. Available at http://www.who.int/countries

Wuthnow, R. (1994). Sharing the journey: Support groups and America's new quest for community. New York: Free Press. 